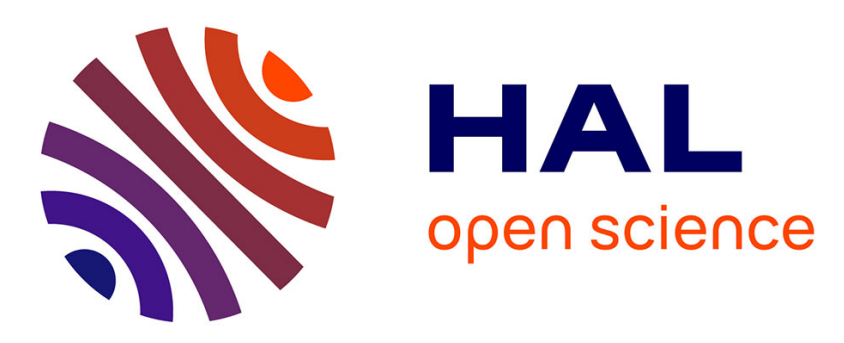

\title{
An energy-based model to analyze growth data of earthworms exposed to two fungicides
}

Sylvain Bart, Céline Pelosi, Sylvie Nelieu, Isabelle Lamy, Alexandre R.R. Pery

\section{To cite this version:}

Sylvain Bart, Céline Pelosi, Sylvie Nelieu, Isabelle Lamy, Alexandre R.R. Pery. An energy-based model to analyze growth data of earthworms exposed to two fungicides. Environmental Science and Pollution Research, 2020, 27 (1), pp.741-750. 10.1007/s11356-019-06985-z . hal-02882422

\section{HAL Id: hal-02882422 \\ https://hal.inrae.fr/hal-02882422}

Submitted on 20 Nov 2020

HAL is a multi-disciplinary open access archive for the deposit and dissemination of scientific research documents, whether they are published or not. The documents may come from teaching and research institutions in France or abroad, or from public or private research centers.
L'archive ouverte pluridisciplinaire HAL, est destinée au dépôt et à la diffusion de documents scientifiques de niveau recherche, publiés ou non, émanant des établissements d'enseignement et de recherche français ou étrangers, des laboratoires publics ou privés. 
1 An energy-based model to analyze growth data of earthworms exposed to two

2 fungicides.

3

4 Sylvain Bart ${ }^{1 *}$, Céline Pelosi ${ }^{1,2}$, Sylvie Nélieu ${ }^{1}$, Isabelle Lamy ${ }^{1}$, Alexandre R.R. Péry ${ }^{1}$

5

$6 \quad{ }^{1}$ UMR ECOSYS, INRA, AgroParisTech, Université Paris-Saclay, 78026, Versailles, France

7 2'UMR EMMAH, INRA, Université d'Avignon et des Pays de Vaucluse, 84914, Avignon, 8 France

9

* Corresponding author: UMR1402 ECOSYS INRA AgroParistech, Bâtiment 6, RD 10, 78026 Versailles cedex, France. Tel: (+33)1.30.83.32.72. ; Fax: (+33)1.30.83.32.59. E-mail address: sylvain1.bart@ outlook.fr . Present email address: sylvain.bart@york.ac.uk 


\section{6}

\section{Abstract}

The pesticide risk assessment for earthworms is currently performed using standardized tests, the model species Eisenia fetida, and the analyses of the data obtained are performed with ad hoc statistical tools. We assessed the impact of two fungicides on the entire growth pattern of the earthworm species Aporrectodea caliginosa, which is highly representative of agricultural fields. Individuals of three different ages (from hatching to 56 days old) were exposed to Cuprafor micro ${ }^{\circledR}$ (copper oxychloride) and Swing ${ }^{\circledR}$ Gold (dimoxystrobin and epoxiconazole). Data were analyzed with an energy-based toxicodynamic model coupled with a toxicokinetic model. The copper fungicide caused a drastic growth inhibition once the No Effect Concentration (NEC), estimated at $65 \mathrm{mg} \mathrm{kg}^{-1}$ of copper, was exceeded. The Swing ${ }^{\circledR}$ Gold negatively affected the growth with NEC values estimated at $0.387 \mathrm{mg} \mathrm{kg}^{-1}$ and $0.128 \mathrm{mg} \mathrm{kg}^{-1}$ for the dimoxystrobin and the epoxiconazole in this fungicide formulation, respectively. The time-profile of the effects on A. caliginosa individuals was fully accounted for by the model, whatever their age of exposure. Furthermore, toxicity data analyses, supported by measurements of fungicide concentrations in earthworm at the end of the experiment, allowed bettering understanding of the mechanisms of action of the fungicides towards earthworm growth.

\section{5} 7 48

49 Keywords: Ecotoxicology, Lumbricidae, Growth, Risk assessment, Toxicokinetictoxicodynamic modelling. 


\section{Introduction}

Pesticides used in agroecosystems can harm biodiversity and biological activity (Bengtsson et al. 2005; Hole et al. 2005). Among non-target soil organisms that can be impacted by pesticides, earthworms are commonly used as biological indicators of chemical stress (OECD, 1984) because they are key soil organisms, involved in nutrient cycling, soil water regulation and aeration (Blouin et al. 2013; Bertrand et al. 2015; Bart et al., 2019a). During the last decades, different ecotoxicological laboratory tests have been developed such as the acute toxicity test (ISO 2012a) or the reproduction tests (ISO 2012b; OECD 2004). In the ISO and OECD tests, the recommended species is Eisenia fetida fetida or Eisenia fetida andrei and they are often used to assess the impacts of pesticides or other chemicals on earthworms. Contrarily, growth tests with earthworms are poorly documented while some authors reported growth to be a very sensitive endpoint (Springett and Gray 1992; Booth et al. 2000; Booth and O'Halloran 2001). Authors highlighted the need to develop a test system for measuring key demographic traits in juvenile earthworms, especially growth (Spurgeon et al. 2004). To move towards a more realistic and relevant assessment of the environmental risks of pesticide use, some issues have to be overcome.

First, the model species (i.e. E. fetida fetida or andrei) do not generally inhabit mineral soils (Lowe and Butt 2007) and are therefore rarely found in cultivated fields where pesticides are applied. To complement the use of E. fetida in pesticide risk assessment procedures, the earthworm species Aporrectodea caliginosa s.s. (Sims and Gerard 1999) was recently proposed as a relevant species to be used in soil ecotoxicology tests (Klobucar et al. 2011; Bart et al. 2018). This species is one of the dominant species in agroecosystems in temperate areas (Boström and Lofs-Holmin 1996; Boag et al. 1997; Curry et al. 2008; Amossé et al., 2018) and is found to be more sensitive to pesticides and metabolites than E. fetida (Pelosi et al. 2013). The second issue in currently used risk assessment procedures is data analyses. Ad 
hoc statistics are used to test differences between effects measured in polluted and unpolluted soils or to calculate no observed effect concentrations (NOEC), lowest observed effect concentrations (LOEC), or effective concentrations (ECx). However, these parameters cannot easily be extrapolated for other exposure durations than the one used for the test, and do not account for the kinetics of the toxicant in soil. To go towards a better understanding of the mechanisms of toxicants on life cycle parameters, energy-based models were proposed to analyze toxicity data (Kooijman and Bedaux 1996). These models are based on the dynamic energy budget (DEB) theory (Kooijman 1986, 2000, 2010) which partitions the use of energy between growth, maintenance, and reproduction. Effects models, called DEBtox models, assume that the use of energy by an organism described in the DEB model can be unbalanced by a toxicant. The effect is described as an impact on one of the parameters of the energybased model and the magnitude of the effects is assumed to be related to the internal concentration of the toxicant of the organism. The exposure concentration and internal concentration of the organisms are related throughout time by a toxicokinetic model. The DEBtox models are toxicokinetic-toxicodynamic models (TK-TD) and have proved their reliability in the analysis of data from growth and reproduction tests (Péry et al. 2002; Jager et al. 2004; Goussen et al. 2013). These models also allow estimating a no effect concentration (NEC) which is a threshold for toxicity that does not depend on the time of exposure. The NEC can be used to compare ecotoxicity of toxicants avoiding time dependency issues of classical parameters such as LOEC, NOEC or $\mathrm{EC}_{\mathrm{x}}$ (Baas et al. 2010; Heckmann et al. 2010; Jager et al. 2014).

We here tested the impact of two widely used commercial formulations of fungicides, that are of interests for the pesticide risk assessment (Bart et al. 2017), on the growth of the earthworm A. caliginosa. The exposure was performed at three different ages to reveal potential differences in earthworm sensitivity over their development. Data were analyzed 
with an energy-based model, calibrated for this species (see supplementary material and Bart et al., 2019b), in order to understand the mechanisms of action and the time-dependence of the two different fungicides on A. caliginosa growth. To support the understanding of the toxicity mechanisms provided by the model, we performed concentration measurements in earthworms at the end of the growth experiment.

\section{Material and methods}

\section{Soil, animals and pesticides.}

All experiments were performed using a loamy soil texture (Based on the texture definition of the Food and Agriculture Organization of the United Nations (FAO)), sampled from a permanent grassland in Versailles $\left(48^{\circ} 48^{\prime} \mathrm{N}, 2^{\circ} 5^{\prime} \mathrm{E}\right)$ where no pesticides have been applied for more than 20 years. The soil was collected from the top $0-20 \mathrm{~cm}$, air-dried and crushed to pass a $2 \mathrm{~mm}$ mesh. Its main physico-chemical characteristics were: $\mathrm{pH} 7.5$, organic matter $32.6 \mathrm{~g} \mathrm{~kg}^{-1}, \mathrm{C} / \mathrm{N} 12.7,29 \%$ sand, $48 \%$ silt, $23 \%$ clay, and $25.2 \mathrm{mg} \mathrm{kg}^{-1}$ of copper (see Bart et al. 2017 for more details).

Aporrectodea caliginosa s.s used in this experiment were bred in the laboratory from individuals initially collected from an agricultural field in Estrée-Mons, France (49o 52 N, 3o 01' E) one year before this study, and determined according to Sims and Gerard (1999). The earthworms were bred in the same soil described above. To get cohorts of hatchlings, cocoons were collected in the breeding culture by wet sieving the soil through a 1-mm mesh size (Bart et al. 2018), and incubated at $20{ }^{\circ} \mathrm{C}$ in Petri dishes on wet filter papers (Holmstrup et al. 1991). Cocoons were checked every two days and new hatchlings were collected and stored in the breeding soil at $4{ }^{\circ} \mathrm{C}$ for a maximum of 1 week, to slow their development. This procedure allowed synchronizing cohorts of individuals to the same level of development (Bart et al. 2018). 

$\mathrm{L}^{-1}$, epoxiconazole $50 \mathrm{~g} \mathrm{~L}^{-1}$ ), used to protect cereal crops in conventional farming. The 128 French Recommended Dose (RD) for this product is $1.5 \mathrm{~L} \mathrm{ha}^{-1}$ on wheat (E-phy 2017a). The $\mathrm{RD}$ in laboratory was calculated as $1.1610^{-3} \mathrm{~mL} \mathrm{~kg}^{-1}$ of dry soil (corresponding to $150 \mu \mathrm{g} \mathrm{kg}^{-}$ ${ }^{1}$ of dimoxystrobin and to $60 \mu \mathrm{g} \mathrm{kg}^{-1}$ of epoxiconazole) with a soil density of 1.29 and considering that the active compounds of this fungicide are mainly found in the top $10 \mathrm{~cm}$ of soil (McDonald et al. 2013; Chabauty et al. 2016). We tested the following concentrations: 0.33, 1, and 3 times the RD, abbreviated SG0.33, SG1, and SG3, respectively. These concentrations were assumed to be sub-lethal considering the LC50 estimated at $7.010^{-3} \mathrm{~mL}$ $\mathrm{kg}^{-1}$ for A. caliginosa (Bart et al. 2017), or 6.03 times the RD.

The second studied fungicide was Cuprafor micro ${ }^{\circledR}$, used to prevent spore germination in organic farming mainly. The French $\mathrm{RD}$ for this product is $10 \mathrm{~kg} \mathrm{ha}^{-1}$ for potato crops and 138 in vineyards (E-phy 2017b). The RD in laboratory was calculated as $15.5 \mathrm{mg} \mathrm{kg}^{-1}$ 139 (corresponding to $7.75 \mathrm{mg} \mathrm{kg}^{-1}$ of copper) of dry soil with a soil density of 1.29 and considering that copper is mainly found in the top $5 \mathrm{~cm}$ of soil (Couto et al. 2015). We tested the following concentrations: $3.33,10$, and 30 times the RD abbreviated $\mathrm{Cu} 3.33, \mathrm{Cu} 10$ and $\mathrm{Cu} 30$, corresponding respectively to $25.8,77.5$, and $232.5 \mathrm{mg} \mathrm{kg}^{-1}$ of copper. These 143 concentrations were assumed to be sublethal (Ma 1984; Spurgeon et al. 2004; Bart et al. 2017; PPDB 2018). Capacity (WHC).

In all experiments, the dry soil was spiked with aqueous solutions of the fungicides, and the soil water holding capacity was adjusted concomitantly at $70 \%$ of the Water Holding 
In order to monitor the growth, the weight of individuals was measured using an analytical

balance $( \pm 0.1 \mathrm{mg})$. The impact of fungicides was tested exposing earthworm juveniles at three different ages: just after hatching, after 28 days of growth in a control soil and after 56 days of growth in a control soil (see Fig. S1 in supplementary material). These three ages were named age 1, age 2 and age 3 respectively (A1, A2 and A3) and individuals weighed 12 $\pm 3 \mathrm{mg}, 90 \pm 15 \mathrm{mg}$ and $300 \pm 40 \mathrm{mg}$ when their exposure began at the three ages, respectively. Under control condition of the experiment, A. caliginosa reach maturity (i.e. apparition of the clitellum) and are able to reproduce after $85 \pm 10$ days of growth and at a weight of $575 \pm 125 \mathrm{mg}$.

Earthworms were placed individually in 1 L plastic vessels $(15 \times 10 \times 7 \mathrm{~cm})$ with $400 \mathrm{~g}$ of soil (dry mass). Seven replicates (each replicate corresponded to one individual) were used per age of exposure and fungicide concentration, including a control without fungicide. All the vessels were stored in a climate room at $15 \pm 1{ }^{\circ} \mathrm{C}$. Individuals were fed with horse dung in ad libitum conditions, as presented in the supplementary material. Individuals were weighed at least every 14 days and the experiment was stopped when individuals had reached maturity, characterized by the apparition of a fully developed clitellum. For the individuals who stopped to grow, without reaching the adult stage, we stopped the experiment after around 35, 70 and 98 days without growth for individuals exposed at Age 3, 2 and 1 respectively. At the end of the experiment, all individuals were placed in petri dishes on damp filter paper for $48 \mathrm{~h}$ in the dark at $15 \pm 1{ }^{\circ} \mathrm{C}$ to void gut contents (Hartenstein et al. 1981). Then, they were weighted and frozen at $-80^{\circ} \mathrm{C}$ for fungicide analysis.

For each treatment, the soil was renewed every 28 days to avoid unsuitable conditions for earthworm growth (e.g. soil compaction). All the soils for a given fungicide treatment were prepared at the same time (see Fig. S1), to ensure a comparable evolution of pesticide concentrations and environmental available fraction. Swing ${ }^{\circledR}$ Gold fungicide concentration in 
177 the soil with earthworms and horse dung and in the new soil was monitored at each soil

178 renewal (see supplementary material for more details). Moreover, in order to characterize the 179 exposure concentration of dimoxystrobin (DMX) and epoxiconazole (EPX), the total 180 concentrations and the environmental available fraction of the active substances were 181 monitored over the time of the experiment, every 28 days.

Fungicide analyses.

The copper fungicide - The soil was sampled just after the soil preparation soils to verify the contamination level. The copper concentration in earthworms at the end of the experiment was also measured in order to quantify the accumulation. Details of the chemicals analyses in soil and earthworms are available in the supplementary material.

The Swing ${ }^{\circledR}$ Gold fungicide - The total soil concentration and of the environmentally available fraction of DMX and EPX were measured over time $(0,28,56$ and 84 days after the contamination) in 4 of the 7 replicates to take into account their dissipation, which changed the earthworm's exposure. These measured concentrations were used in the toxicokinetic model. The DMX and EPX concentration in earthworms at the end of the experiment was also measured in order to quantify the accumulation. Details of the chemicals analyses in soil and earthworms are available in the supplementary material.

The energy-based model.

We used a growth model shortly presented in the supplementary material and fully 199 presented in Bart et al., (2019b). This model is based on the DEB theory (Dynamic Energy Budget) (Kooijman 1986, 2000, 2010). Under ad libitum conditions and according to the 
assumptions of isomorphism and neglected energy costs of maintenance, the growth is expressed with the following equation:

$$
\text { If } l<C s \text {, then } \frac{d}{d t} l=a(1-b)
$$

$$
\text { If } l>C s, \text { then } \frac{d}{d t} l=a
$$

Where $l$ is the cubic root of the wet weight of the organisms, $C s$ is the Critical size (below which the individual cannot access all the food) $a$ is a constant and $b$ is a food accessibility factor to take into account that when individuals are too small, they cannot access the whole food quantity. In our experimental conditions, the parameter values were optimized with the control treatment as follows $C s=3.99, a=0.075$ and $b=0.13$.

\section{The toxicokinetic/toxicodynamic (TK/TD) model.}

The effect model is based on the energy-based model mentioned above. We assumed that the exposure to the toxicant increases the energy cost of growth. As in the DEBtox model (Kooijman and Bedaux 1996), we assumed that there is a threshold for effect, a no effect concentration (NEC), and that the effects are proportional to the difference between the internal concentration and the NEC value. The toxicokinetic of the internal concentration $(\mathrm{Ci})$ was deduced from the exposure concentration with a one compartment model:

$$
\frac{d C i}{d t}=K u x c e(t)-K e x C i(t)
$$

where $K u$ and $K e$ are the uptake and the elimination rate, $c e$ and $C i$ are the external and internal concentrations of the toxicant, respectively. However, because we do not have 
access to the internal concentration, it was scaled by the bio-concentration factor as explained in a previous study (Péry et al. 2001), leading to the following equation:

$$
\begin{gathered}
\frac{d c i(t)}{d t}=K e(c e(\mathrm{t})-c i(\mathrm{t})) \\
\text { with } c i=C i \frac{K e}{K u}
\end{gathered}
$$

224

Where $\mathrm{c} i$ is proportional to the internal concentration, but corresponds to an external concentration. Moreover, the individuals had a measurable growth during the experiment which led to a dilution by growth (the earthworm increased biomass reduced the internal concentration). We accounted for this in the toxicokinetic model (Kooijman and Bedaux, 2010). The elimination rate is assumed to be proportional to the ratio of the surface area to the volume, and thus inversely proportional to the length for an isomorphic organism as explained theoretically (Kooijman and Bedaux, 2010) and shown experimentally (Sijm and van der Linde 1995; Sijm et al. 1995). This is why the elimination rate must be divided by a scaled length if the body size changes leading to the following equation:

$$
\frac{d c i(t)}{d t}=\frac{K e(c e(\mathrm{t})-c i(\mathrm{t}))}{l}-\frac{3 a c i}{l}
$$

In the case of an increase in the growth costs, we assumed that the costs of building a cell are multiplied by a factor $1+e(c i(\mathrm{t})-\mathrm{NEC}), e$ being a constant and accounting for the level of toxicity as soon as the NEC is exceeded by the scaled internal concentration, leading to the following equation:

$$
\text { If } l<C s \text {, then } \frac{d}{d t} l=\frac{a(1-b)}{1+e(c i-\mathrm{NEC})}
$$




$$
\text { If } l>C s, \text { then } \frac{d}{d t} l=\frac{a}{1+e(c i-\mathrm{NEC})}
$$

241

242

243 infinite value for $e$ :

\section{Results}

\section{The copper fungicide}

All the parameters $(K e, \mathrm{NEC}$ and $e$ ) were simultaneously calibrated for each fungicide (including the three different ages of exposure).

\section{Model calibration and statistical analyses.}

The differential equations were implemented in the software R Core Team (2015), and solved with the package deSolve (Soetaert et al. 2010). The model was fitted to the data, for all concentrations and ages of exposure for each fungicide, using the least square method. The bootstrap method ${ }^{45}$ was used for the estimation of the confidence intervals of the parameters. The $\mathrm{R}$ script is available on request to the corresponding author.

The copper contamination led to a drastic growth inhibition in the $\mathrm{Cu} 10$ and $\mathrm{Cu} 30$ treatments (Fig. 1). We thus chose to simplify the toxicodynamic model as follows, with an

$$
\text { If } c i>N E C \text {, then } \frac{d}{d t} l=0(7)
$$


In this situation, there were only two parameters to calibrate in the model: $K e$ and the

NEC. The parameter $K e$ was estimated at 1.19 and the NEC at $65 \mathrm{mg} \mathrm{kg}^{-1}$ of copper (Table 1). These parameter values were common to the three different ages.

Table 1. Estimated parameter values and confidence intervals (CI 95\%) for the copper fungicide.

\begin{tabular}{lll}
\hline Parameters & Value & CI $(95 \%)$ \\
\hline Ke & 1.19 & $1.17-1.67$ \\
NEC copper $\left(\mathrm{mg} \mathrm{kg}^{-1}\right)$ & 65.006 & $64.79-65.01$ \\
$e$ & infinite & - \\
\hline
\end{tabular}

Fig. 1 presents the growth data and the description by our model. The data were not significantly different from the model description in $59 \%$ of the cases $(\mathrm{P}>0.05$ with Student's t-tests). The difference was mainly due to over-estimation of the asymptotic mass of individuals of age 3 exposed to $\mathrm{Cu} 10$ and $\mathrm{Cu} 30$ treatment, and under-estimation of the asymptotic mass of individuals of age 1 exposed to the $\mathrm{Cu} 10$ treatment.

The copper fungicide applied at $25.8 \mathrm{mg} \mathrm{kg}^{-1}$ of copper did not impact the growth for the 3 different ages of exposure because the NEC was not exceeded (Fig. 1). The growth pattern in this treatment thus corresponded to the growth pattern provided by the model in the control. At $77.5 \mathrm{mg} \mathrm{kg}^{-1}$ of copper, an inhibition of the growth was observed, appearing at different times after the beginning of the exposure for the different ages: the effects appeared immediately after the exposure for new-hatched individuals (Age 1) and after respectively 20 and 30 days after the exposure for individuals of Age 2 and 3. The model accounted for these differences through the dilution by growth in the toxicokinetic model and provided a good description of the data although it slightly overestimated the growth of the bigger juveniles 
283 (Age 3). At $232.5 \mathrm{mg} \mathrm{kg}^{-1}$ of copper, the growth was totally inhibited right after the beginning 284 of the exposure, whatever the age of the earthworms. Our model also accounted for this absence of difference between ages.
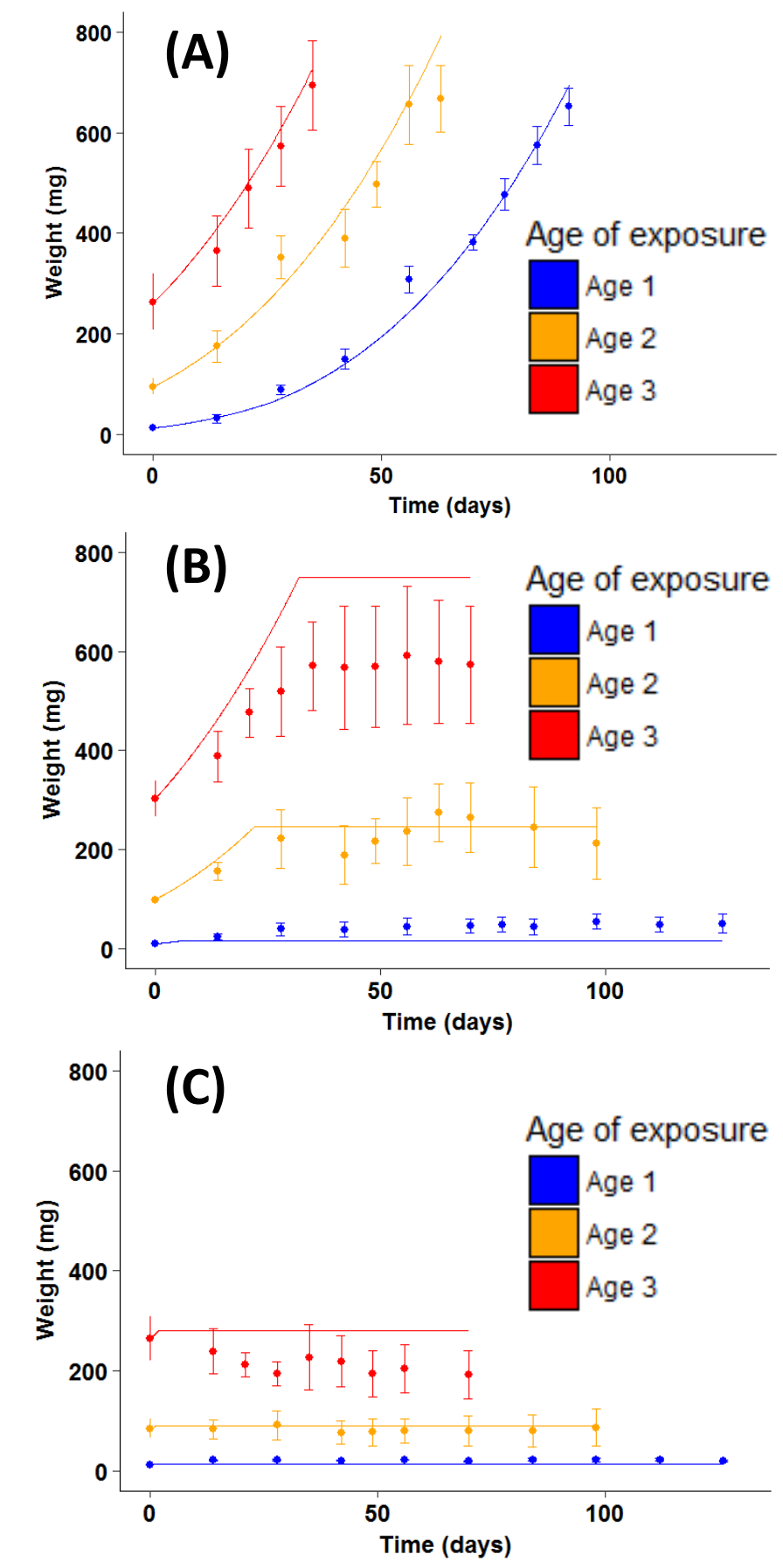

287 Fig. 1 Growth pattern of A. caliginosa juveniles exposed at different ages to the Cuprafor 288 micro $^{\circledR}$ fungicide at (A) 3.33 times the RD (Recommended Dose), corresponding to $25.8 \mathrm{mg}$ $289 \mathrm{~kg}^{-1}$ of copper, (B) 10 times the RD, corresponding to $77.5 \mathrm{mg} \mathrm{kg}^{-1}$ of copper, and (C) 30 
292

293

294

295

$250-$

$0^{-}$

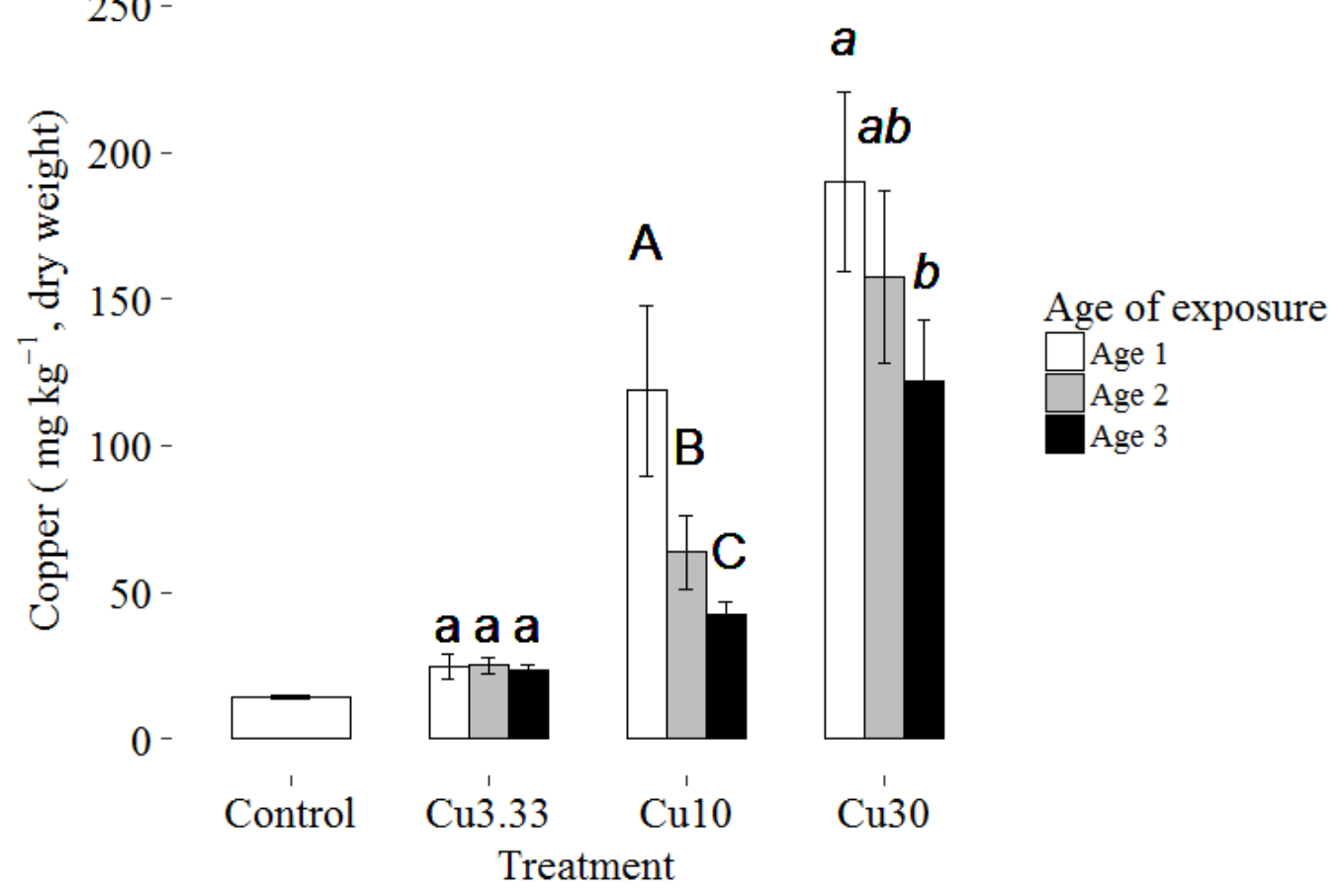

times the RD, corresponding to $232.5 \mathrm{mg} \mathrm{kg}^{-1}$ of copper. Full lines represent the description of the observations ( $n=7 \pm S D$ ) by the model.

The copper accumulation in earthworm significantly differed between treatments and the control (Fig. 2). At $25.8 \mathrm{mg} \mathrm{kg}^{-1}$ of copper (Cu3.33), the copper internal concentration at the end of the experiment did not differ between individuals exposed at Age 1, 2, or 3. For the individuals exposed in the $\mathrm{Cu} 10$ and $\mathrm{Cu} 30$ treatments, the copper concentration in tissues significantly decreased with increase of the age of exposed earthworms corresponding to an increase in copper accumulation with the time of exposure (Fig. 2).

Fig. 2 Copper concentration in A. caliginosa individuals at the end of the growth experiment 303 in $\mathrm{mg} \mathrm{kg}^{-1}$ (dry weight). Individuals of Age 1 were exposed for on average 91 days to the $304 \mathrm{Cu} 3.33\left(25.8 \mathrm{mg} \mathrm{kg}^{-1}\right.$ of copper) treatment and 126 days to $\mathrm{Cu} 10$ (77.5 mg kg $\mathrm{mg}^{-1}$ of copper) and $\mathrm{Cu} 30$ (232.5 $\mathrm{mg} \mathrm{kg}^{-1}$ of copper). Individuals of Age 2 were exposed for on average of 63 days 
to the $\mathrm{Cu} 3.33$ treatment and 98 days for the $\mathrm{Cu} 10$ and $\mathrm{Cu} 30$ treatment. Individuals of Age 3 were exposed for on average of 35 days to the $\mathrm{Cu} 3.33$ treatment and 70 days to the $\mathrm{Cu} 10$ and Cu30 treatment. Different letters mean significant differences between ages of exposure for each copper treatment.

\section{The Swing ${ }^{\circledR}$ Gold fungicide}

The effects of Swing ${ }^{\circledR}$ Gold on the growth appeared immediately after the start of exposure in the SG3 treatment (Fig. 3C). We thus assumed a very fast toxicokinetics and used directly the total DMX or EPX soil concentration as internal concentration $(c i)$ in the effect model. Two parameters were thus calibrated: $e$ and the NEC. The parameter $e$ was estimated at 13.27 and 13.24 for the DMX and the EPX in the Swing ${ }^{\circledR}$ Gold formulation respectively (Table 2). The NEC was estimated at $0.387 \mathrm{mg} \mathrm{kg}^{-1}$ (dry soil) and $0.128 \mathrm{mg} \mathrm{kg}^{-1}$ of DMX and EPX in the Swing ${ }^{\circledR}$ Gold formulation respectively (Table 2). These parameter values were common to the three different ages.

Table 2. Estimated parameter values and confidence intervals (CI 95\%) for the Swing ${ }^{\circledR}$ Gold fungicide.

\begin{tabular}{lll}
\hline Parameters & Value & CI (95\%) \\
\hline Ke & infinite & - \\
NEC Dimoxystrobin $\left(\mathrm{mg} \mathrm{kg}^{-1}\right)$ & 0.387 & $0.375-0.402$ \\
NEC Epoxiconazole $\left(\mathrm{mg} \mathrm{kg}^{-1}\right)$ & 0.128 & $0.123-0.143$ \\
$e$ Dimoxystrobin & 13.27 & $11.98-21.00$ \\
$e$ Epoxiconazole & 13.24 & $13.22-44.18$ \\
\hline
\end{tabular}

Fig. 3 presents the growth data and the description by our model. The data were not significantly different from the model description in $81 \%$ of the cases $(\mathrm{P}>0.05$ with Student's t-tests). The growth of individuals exposed at 0.33 and 1 times the RD (SG0.33 and 
328 SG1) was not affected because the NEC was not exceeded. In these treatments, the growth

329 pattern thus corresponded to the growth pattern provided by the model in the control (Fig. 3A

330 and 3B). At 3 times the RD (SG3), the growth was negatively affected just after the exposure

331 whatever the age of exposure (Fig. 3C), and during a period of 15 days corresponding to the

332 time during which the concentration exceeded the NEC.
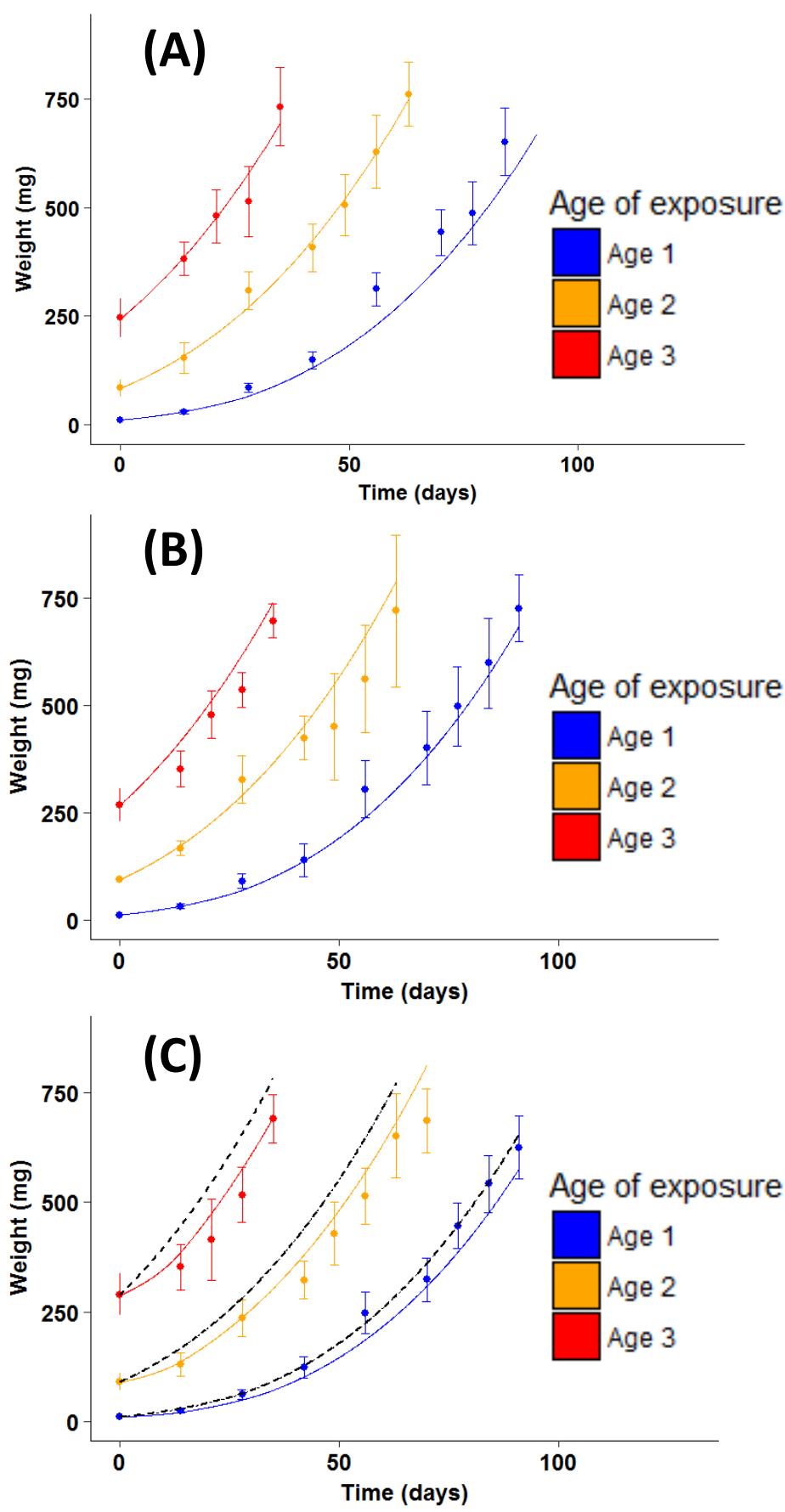
335 Fig. 3 Growth pattern of A. caliginosa exposed at different ages to the Swing ${ }^{\circledR}$ Gold fungicide 336 at (A) 0.33 times the RD (Recommended Dose) corresponding to $5.2 \times 10^{-2} \mathrm{mg} \mathrm{kg}^{-1}$ of DMX 337 and $1.94 \times 10^{-2} \mathrm{mg} \mathrm{kg}^{-1}$ of EPX. (B) 1 time the RD corresponding to $1.55 \times 10^{-1} \mathrm{mg} \mathrm{kg}^{-1}$ of 338 DMX and $5.81 \times 10^{-2} \mathrm{mg} \mathrm{kg}^{-1}$ of EPX. (C) 3 times the RD corresponding to $4.62 \times 10^{-1} \mathrm{mg}$ $339 \mathrm{~kg}^{-1}$ of DMX and $1.74 \times 10^{-1} \mathrm{mg} \mathrm{kg}^{-1}$ of EPX. Full lines represent the description of 340 observations $(\mathrm{n}=7 \pm \mathrm{SD})$ by the model, and the dash lines represent the description of the 341 observations in the control treatment by the model.

The DMX and EPX accumulation in earthworm significantly differed between the 344 treatments and the control (Fig. 4). There was no significant difference in the accumulation of

345 DMX or EPX between the different ages of exposure corresponding to no difference accumulation with the time of exposure (Fig. 4). 

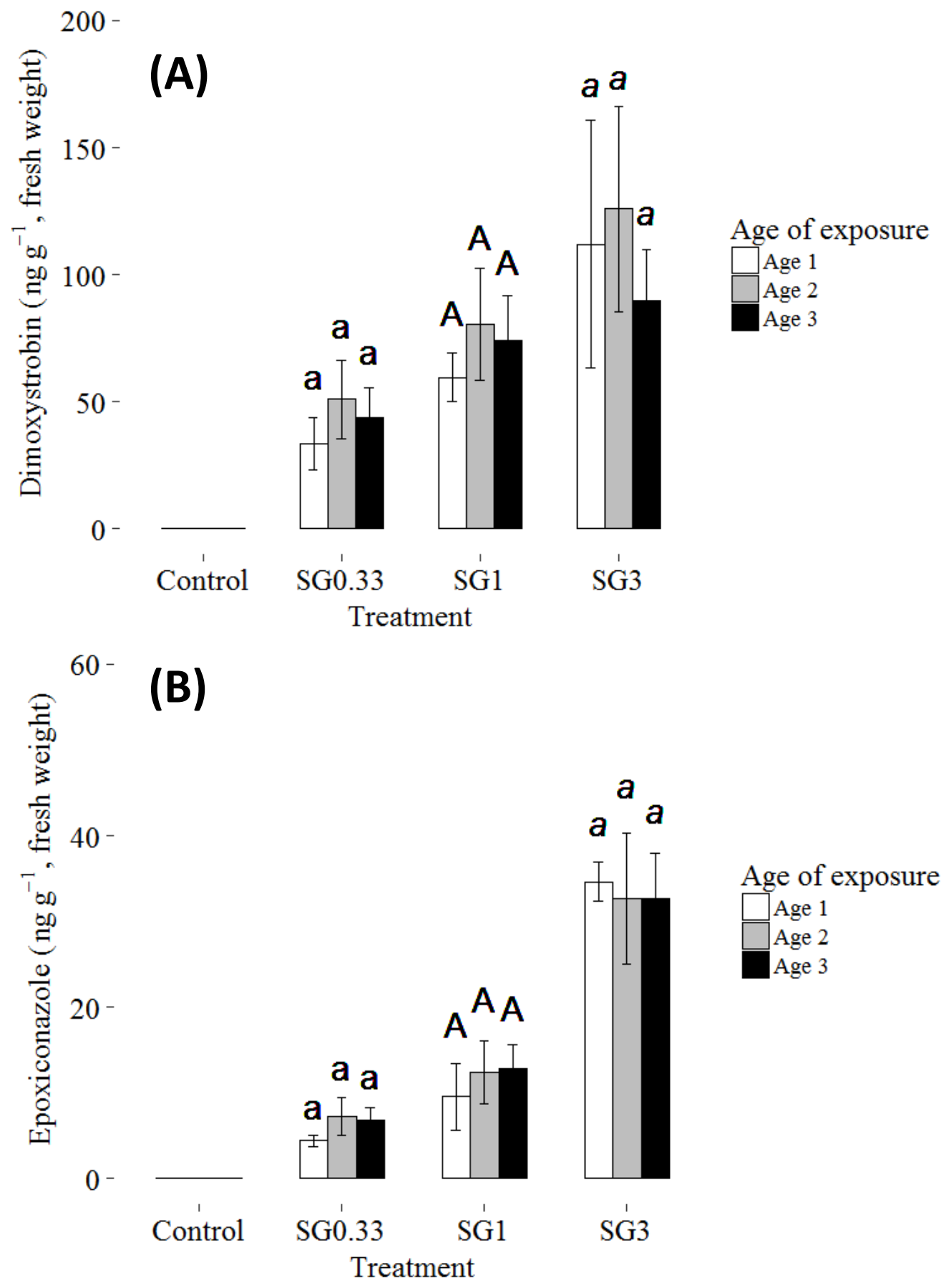

348 Fig. 4 Concentration of dimoxystrobin (A) and epoxiconazole (B) in A. caliginosa individuals 349 at the end of the growth experiment in $\mathrm{ng} \mathrm{g}^{-1}$ (fresh weight). Individuals of Age 1 were exposed for on average 91 days to the SG 0.33 and SG1 treatment and 95 days to the SG3 treatment. Individuals of Age 2 were exposed for on average 63 days to the SG 0.33 and SG1 treatment and 67 days to the SG3 treatment. Individuals of Age 3 were exposed an average 35 days to the SG 0.33 and SG1 treatment and 38 days to the SG3 treatment. Different letters mean significant differences between ages of exposure for each Swing ${ }^{\circledR}$ Gold treatment. 


\section{Discussion}

\section{Impact of the two tested fungicides on earthworm growth.}

We here showed that the growth pattern of one of the most representative species of earthworms in cultivated fields was highly influenced by the presence of two fungicides at environmentally relevant doses. Moreover, we highlighted that the magnitude of the effects depend on the age of the individuals. Finally, we pointed out that the model proposed in the supplementary material coupled with a TK-TD model can be very useful to understand impacts and provide threshold value of the ecotoxicity of the tested fungicides.

The copper fungicide appeared highly harmful to earthworm growth beyond the NEC, estimated at $65 \mathrm{mg} \mathrm{kg}^{-1}$ of copper, corresponding to 8.4 times the RD of the fungicide. This result is in accordance with the EC50 growth estimated at $81.8 \mathrm{mg} \mathrm{kg}^{-1}$ of copper in a previous study (Khalil et al. 1996). Others authors showed that copper affected the growth of E. fetida from $8.92 \mathrm{mg} \mathrm{Cu} \mathrm{kg} \mathrm{substrate}{ }^{-1}$ (which was urine-free cattle manure) and that earthworms exposed to $346.85 \mathrm{mg} \mathrm{Cu} \mathrm{kg} \mathrm{substrate}{ }^{-1}$ exhibited hardly any increase in weight (Helling et al. 2000). It has also been showed that copper inhibited the growth of the earthworm Lumbricus rubellus at a concentration of $370 \mathrm{mg} \mathrm{kg}^{-1}$ of copper in a sandy soil (Ma 1984). It thus appears that copper is harmful for earthworm growth but the threshold concentration inducing impact is highly dependent on the soil characteristics and species considered (Ma and Rao 1997, EU 2008). Finally, it is important to notice that the NEC value estimated (i.e. $65 \mathrm{mg} \mathrm{kg}^{-1}$ ) could be reached in agricultural systems because copper accumulates in soils (Brun et al. 1998). This is the case in vineyards in which copper can reach more than $100-200 \mathrm{mg} \mathrm{kg}^{-1}$ and explain the very low density of earthworms in these agroecosystems (Paoletti et al. 1998). 

NEC value of 2.5 times the RD. Moreover, DMX and EPX have estimated DT50 values (lab at $20^{\circ} \mathrm{C}$ ) of 210 and 226 days respectively (PPDB, 2018), suggesting that these compound

382 could accumulate and persist in the environment. The NEC values provided in this study are valid only in the studied commercial formulation and we could not determine which of the two substances caused the effect on growth. However, literature suggest that DMX is more harmful than EPX based on LC50 values (Pelosi et al. 2016; PPDB, 2018).

Growth is a key component of the life history parameter that directly influences the population dynamics in a way comparable to reproduction or survival. In the fields, earthworms are active between 3 and 7 months per year, generally in spring and autumn (Baker et al. 1992). In the present study, A. caliginosa individuals in the control soil took three months to become adult in optimal conditions (fed ad libitum, soil moisture of $70 \%$ of the WHC, temperature at $15^{\circ} \mathrm{C}$, Bart et al. 2018). We can thus assume that there would be no more than one or two new generations of A. caliginosa per year. And it is worthwhile to underline that A. caliginosa grow and reproduce relatively fast (Bart et al. 2018, Bart et al., 2019c) compared to other species of earthworms such as anecic species (e.g. Lumbricus terrestris, Butt 1993; Pelosi et al. 2008. or Octolasion cyaneum, Butt 1993). A growth delay of about ten percent, as we observed for Swing ${ }^{\circledR}$ Gold, could have a strong impact on the population dynamics, with adults appearing significantly later in the year at a period which could not be optimal for the reproduction. It could be even more problematic with compounds such as copper that completely inhibit earthworm growth. 


\section{Relevance of the toxicity analysis with TK-TD model.}

405

406

407

408

409

410

411

412

The two tested fungicides had very different toxicokinetics and toxicodynamics. For the copper fungicide, we showed a drastic inhibition of growth and a slow kinetics whereas the toxicokinetics for the Swing ${ }^{\circledR}$ Gold fungicide was very fast with moderate effects. These conclusions came from the analysis of the data with our TK-TD model which indicated the relevance of assuming either very fast kinetics or very strong effects. The conclusions regarding the kinetics were confirmed with the measurements of the fungicide internal concentrations at the end of the experiment.

We saw that the effects of the copper fungicide significantly depended on the age of the exposed individuals and the exposure duration. Indeed, the effects appeared earlier for small organisms (Age 1) compared to older organisms (Age 2 and 3) and that was accounting for by the dilution by growth and the influence of weight on the kinetics parameters. Thus, the difference between ages is fully explained by growth, with same parameters for kinetics and effects. This also supports that the use of a one compartment-model was satisfactory here. In some cases, for which, for instance, uptake rate depends on exposure concentrations because of saturation of the uptake, a model with more compartments could be necessary (Steen Redeker and Blust 2004). The difference in copper accumulation was certainly due to the longer exposure of individuals of Age 1 and 2, because low elimination rates mean that the longer the exposure the higher the accumulation. Still after more than 90 days of exposure, the plateau for accumulated concentration was thus still not reached. For the Swing ${ }^{\circledR}$ Gold fungicide, EPX and DMX accumulation in earthworms did not differ between the different ages and times of exposure. This is consistent with rapid kinetics, which implies no dependence between the accumulated concentration and the exposure duration. However, further work on the accumulation in earthworm are required to validate our work. The model, 
which accounts for the exposure throughout time, take into account that the two active substances of the Swing ${ }^{\circledR}$ Gold fungicide degraded over time, and we were able to explain the toxicodynamics. Indeed, the total concentration in soil became lower than the NEC after 15 days of exposure to the highest nominal concentration (SG3) and the growth was not affected anymore afterwards.

In this study, we hypothesized that the physiological mode of action of the two tested fungicides was an increase in the growth energy costs. Another possible effect on growth could have occurred through a decrease in the feeding rate. From a modeling point of view, it is tricky to assess which model would fit at best the observed data because they are very similar for small concentrations. To make the difference between these two modes of action, authors performed experiments in two feeding conditions, ad libitum and limited food conditions (Péry et al. 2003). Here, we only used ad libitum conditions. For copper, some elements in the literature support the assumption of an increase in growth cost. First, this was the mode of action found for chironomids (Péry et al. 2003). Moreover, the increase in growth energy costs could be linked to detoxification process. For example, it has been showed for Lumbricus rubellus that the production of metallothionein (MT) proteins increased 5-fold in soil contaminated with copper compared to a control soil (Stürzenbaum et al. 1998). The same has been shown with E. fetida exposed to cadmium (Brulle et al. 2007). The MT(s) are responsible for detoxification processes after an exposure to a metal contamination. The energy could be redirected to the production of such proteins in response to the contamination.

\section{Environmental implications.}



in the ecological risk assessment of pesticide. First, the threshold values are, as for the

455 reproduction (Neuhauser et al. 1985), lower than the LC50 value (based on survival). Moreover, growth can have a strong impact on population dynamics that determines the occurrence in the field and the related provided functions. The strength of our study relies on the ability of the TK-TD model to fit, with the same parameters, the data obtained for three different ages of exposure, despite apparent differences in the toxicodynamics. The NEC values provided are common to all ages of exposure and do not depend on the time of exposure as for ECx values. Finally, TK-TD models are interesting tools that can be used in the regulatory risk assessment to assess bioaccumulation and effects of pesticides as it is suggested for aquatic organisms in a recent EFSA report (EFSA, 2018).

\section{Supplementary material}

Figure of the experimental design. Description of the growth energy-based model. Chemical analysis methods, and results.

\section{Acknowledgements}

Authors thank Jodie Thénard, Véronique Etievant, Jean-Pierre Pétraud, Sacha Roudine, and Alexandre Barraud for their help and technical assistance. Authors also thank Ghislaine Delarue, Amélie Trouvé and Sébastien Breuil for pesticide analyses. Authors thank Rémy Beaudouin for the discussion on the energy-based modelling. This work is supported by the "IDI 2015" project funded by the IDEX Paris-Saclay, ANR-11-IDEX-0003-02.

\section{References}


Amosse J, Bart S, Pery ARR, Pelosi C (2018) Short-term effects of two fungicides on enchytraeid and earthworm communities under field conditions. Ecotoxicology 27(3): $300-312$.

Baas J, Jager T, Kooijman B (2010) Understanding toxicity as processes in time. Sci Total Environ 408: 3735-3739

Baker GH, Barrett R, Grey-Gardner R, Buckerfield JC (1992) The life history and abundance of the introduced earthworms Aporrectodea trapezoides and A. caliginosa (AnneUda: Lumbricidae) in pasture soils in the Mount Lofty Ranges, South Australia. Aus J Ecol 17: $177-188$

Bart S, Amossé J, Lowe CN, Péry ARR, Mougin C, Pelosi C (2018) Aporrectodea caliginosa, a relevant earthworm species for a posteriori pesticide risk assessment: Current knowledge and recommendations for culture and experimental design. Environ Sci Pollut Res 25: 33867

Bart S, Barraud A, Amosse J, Pery ARR, Mougin C, Pelosi C (2019c) Effects of two common fungicides on the reproduction of Aporrectodea caliginosa in natural soil. Ecotoxicol Environ Saf 181: 518-524.

Bart S, Laurent C, Péry ARR, Mougin C, Pelosi C (2017) Differences in sensitivity between earthworms and enchytraeids exposed to two commercial fungicides. Ecotoxicol Environ Saf 140: $177-184$

Bart S, Pelosi C, Barraud A, Péry ARR, Cheviron N, Grondin V, Mougin C and Crouzet O (2019a) Earthworms Mitigate Pesticide Effects on Soil Microbial Activities. Front Microbiol 10:1535

Bart S, Pelosi C, Péry ARR (2019b) Towards a better understanding of the life cycle of the earthworm Aporrectodea caliginosa: new data and energy-based modelling. Pedobiologia. In press 
Bengtsson J, Ahnstrom J, Weibull AC (2005) The effects of organic agriculture on biodiversity and abundance: a meta-analysis. J Appl Ecol 42: 261-269

Bertrand M, Barot S, Blouin M, Whalen J, de Oliveira T, Roger-Estrade J (2015) Earthworm services for cropping systems. A review. Agron Sustain Dev 35: 553-567

Blouin M, Hodson ME, Delgado EA, Baker G, Brussaard L, Butt KR, Dai J, Dendooven L, Peres G, Tondoh JE, Cluzeau D, Brun JJ (2013) A review of earthworm impact on soil function and ecosystem services. Eur J Soil Sci 64: 161-182

Boag B, Palmer LF, Neilson R, Legg R, Chambers SJ (1997). Distribution, prevalence and intensity of earthworm populations in arable land and grassland in Scotland. Ann Appl Biol 130(1): 153-165

Booth LH, Heppelthwaite VJ, O'Halloran K (2000) Growth, development and fecundity of the earthworm Aporrectodea caliginosa after exposure to two organophosphates. N Z Plant Prot 53: 221-225

Booth LH, O'Halloran K (2001) A comparison of biomarker responses in the earthworm Aporrectodea caliginosa to the organophosphorus insecticides diazinon and chlorpyrifos. Environ Toxicol Chem 20(11): 2494-2502

Boström U, Lofs-Holmin A (1996) Annual population dynamics of earthworms and cocoon production by Aporrectodea caliginosa in a meadow fescue ley. Pedobiologia 40(1): 3242

Brulle F, Mitta G, Leroux R, Lemiere S, Lepretre A, Vandenbulcke F (2007) The strong induction of metallothionein gene following cadmium exposure transiently affects the expression of many genes in Eisenia fetida: a trade-off mechanism? Comp Biochem Physiol C Toxicol Pharmacol 144: 334-41 
523 Brun LA, Maillet J, Richarte J, Herrmann P, Remy JC (1998) Relationships between extractable copper, soil properties and copper uptake by plants in vineyards soils. Environ Pollut 102: 151-161

Butt, K.R., 1993. Reproduction and growth of three deep-burrowing earthworms (Lumbricidae) in laboratory culture in order to assess production for soil restoration. Biology and Fertility of Soils, 16(2), pp.135-138.

Chabauty F, Pot V, Bourdat-Deschamps M, Bernet N, Labat C, Benoit P (2016) Transport of organic contaminants in subsoil horizons and effects of dissolved organic matter related to organic waste recycling practices. Environ Sci Pollut Res Int 23 (7): 6907-6918

Couto RR, Benedet L, Comin JJ, Belli Filho P, Martins SR, Gatiboni LC, Radetski M, Valois, CM, Ambrosini VG, Brunetto G (2015) Accumulation of copper and zinc fractions in vineyard soil in the mid-western region of Santa Catarina, Brazil. Environ Earth Sci 73(10): 6379-6386

Curry JP, Doherty P, Purvis G, Schmidt O (2008) Relationships between earthworm populations and management intensity in cattle-grazed pastures in Ireland. Appl Soil Ecol 39(1): $58-64$

E-phy (2017a) https://ephy.anses.fr/ppp/swing-gold

E-phy (2017b) https://ephy.anses.fr/ppp/styrocuivre-df

Efron B (1979) Bootstrap methods: another look at the jacckknife. Annals stat 7 (1): 1-26

EU (2008) European Union Risk Assessment Report. Voluntary risk assessment of copper, copper II sulphate pentahydrate, copper(I)oxide, copper(II)oxide, dicopper chloride trihydroxide. Summary of the Terrestrial Effect Chapter. PNEC derivation for copper in the terrestrial environment. 
Goussen B, Parisot F, Beaudouin R, Dutilleul M, Buisset-Goussen A, Péry ARR, Bonzom JM (2013) Consequences of a multi-generation exposure to uranium on Caenorhabditis elegans life parameters and sensitivity. Ecotoxicology 22: 869-878

Hartenstein F, Hartenstein E, Hartenstein R (1981) Gut load and transit time in the earthworm Eisenia foetida. Pedobiologia 22: 5-20

Heckmann LH, Baas J, Jager T (2010) Time is of the essence. Environ Toxicol Chem 29: $1396-1398$

Helling B, Reinecke SA, and Reinecke AJ (2000) Effects of the fungicide copper oxychloride on the growth and reproduction of Eisenia fetida (Oligochaeta). Ecotoxicol Environ Saf 46: $108-116$

Hole DG, Perkins AJ, Wilson JD, Alexander IH, Grice PV, Evans AD (2005) Does organic farming benefit biodiversity? Biol Conserv 122: 113-130

Holmstrup M, Ostergaard IK, Nielsen A, Hansen BT (1991) The relationship between temperature and cocoon incubation-time for some lumbricoid earthworm species. Pedobiologia 35(3): 179-184

ISO (International Organisation for Standardization) (2012a) Soil Quality - Effects of Pollutants on Earthworms - Part 1: Determination of Acute Toxicity to Eisenia fetidal Eisenia andrei. No. 11268-1. Geneva

ISO (International Organization for Standardization) (2012b) Effects of pollutants on earthworms (Eisenia fetida). Part 2: determination of effects on reproduction-No. 112682. Geneva

Jager T, Crommentuijn T, Van Gestel CAM, Kooijman SALM (2004) Simultaneous modeling of multiple endpoints in life-cycle toxicity tests. Environ Sci Technol 38: 28942900 
Jager T, Gudmundsdottir EM, Cedergreen N (2014) Dynamic modeling of sublethal mixture toxicity in the nematode Caenorhabditis elegans. Environ Sci Technol 48, 7026-7033

Khalil MA, Abdel-Lateif HM, Bayoumi BM, van Straalen NM (1996) Analysis of separate and combined effects of heavy metals on the growth of Aporrectodea caliginosa (Oligochaeta; Annelida), using the toxic unit approach. Appl Soil Ecol 4: 213-219

Klobucar GIV, Stambuk A, Srut M, Husnjak I, Merkas M, Traven L, Cvetkovic Z (2011) Aporrectodea caliginosa, a suitable earthworm species for field based genotoxicity assessment? Environ Pollut 159: 841-849

Kooijman SALM, Bedaux JJM (1996) The Analysis of Aquatic Toxicity Data. Vu University Press, Amsterdam.

Kooijman SALM (1986). Energy budgets can explain body size relations. J. Theor. Biol. 121, $269-282$

Kooijman SALM (2000) Dynamic energy and mass budgets in biological systems. Cambridge: Cambridge University Press, 423 pages.

Kooijman SALM (2010) Dynamic Energy Budget theory for metabolic organization. Cambridge University Press, Great Britain ISBN 9780521131919.

Lowe CN, Butt KR (2007) Earthworm culture, maintenance and species selection in chronic ecotoxicological studies: a critical review. Eur J Soil Biol 43: S281-S288

Ma W (1984) Sublethal toxic effects of copper on growth, reproduction and litter breakdown activity in the earthworm slumbricus rubellus, with observations on the infuence of temperature and soil ph. Environ Pollut Ser. A 33, 207219.

Ma LQ, Rao GN (1997) Chemical fractionation of cadmium, copper, nickel, and zinc in contaminated soils. J Environ Qual 26: 259-264 
McDonald J, Gaston L, Elbana T, Andres K, Crandfield E (2013) Dimoxystrobin sorption and degradation in sandy loam soil: impact of different landscape positions. Soil Sci 178: 662670

Neuhauser EF, Loehr RC, Malecki MR, Milligan DL, Durkin PR (1985) The toxicity of selected organic-chemicals to the earthworm Eisenia fetida. J Environ Qual 14: 383-388

OECD (Organization for Economic Co-operation and Development) (2004) Earthworm Reproduction Test (Eisenia fetida/Eisenia andrei) (No. 222). OECD Guidelines for the Testing of Chemicals. OECD, Paris, France.

OECD (Organization for Economic Co-operation and Development) (1984) Guideline for the testing of chemicals. No. 207. Earthworm, acute toxicity tests. OECD Publishing, Paris

EFSA PPR Panel (EFSA Panel on Plant Protection Products and their Residues), Ockleford C, Adriaanse P, Berny P, Brock T, Duquesne S, Grilli S, Hernandez-Jerez AF, Bennekou SH, Klein M, Kuhl T, Laskowski R, Machera K, Pelkonen O, Pieper S, Smith RH, Stemmer M, Sundh I, Tiktak A, Topping CJ, Wolterink G, Cedergreen N, Charles S, Focks A, Reed M, Arena M, Ippolito A, Byers H and Teodorovic I (2018) Scientific Opinion on the state of the art of Toxicokinetic/Toxicodynamic (TKTD) effect models for regulatory risk assessment of pesticides for aquatic organisms. EFSA J 16(8):e05377

Paoletti MG, Sommaggio D, Favretto MR, Petruzzelli G, Pezzarossa B, Barbafieri M (1998) Earthworms as useful bioindicators of agroecosystem sustainability in orchards and vineyards with different inputs. Appl Soil Ecol 10: 137-150

Pelosi C, Bertrand M, Makowski D, Roger-Estrade J (2008) WORMDYN: A model of Lumbricus terrestris population dynamics in agricultural fields. Ecol Modell 218: 219-234

Pelosi C, Joimel S, Makowski D (2013) Searching for a more sensitive earthworm species to be used in pesticide homologation tests - a meta-analysis. Chemosphere 90: 895-900 
Pelosi C, Lebrun M, Beaumelle L, Cheviron N, Delarue G, Nelieu S (2016) Sublethal effects of epoxiconazole on the earthworm Aporrectodea icterica. Environ Sci Pollut Res 23(4): 3053-3061

Péry ARR, Bedaux JJM, Zonneveld C and Kooijman SALM (2001) Analysis of bioassays with time-varying concentrations. Wat Res 35: 3825-3832

Péry ARR, Ducrot V, Mons R, Garric J (2003) Modelling toxicity and mode of action of chemicals to analyse growth and emergence tests with the midge Chironomus riparius. Aquat Toxicol 65: 281-292

Péry ARR, Flammarion P, Vollat B, Bedaux JJM, Kooijman SALM, Garric J (2002) Using a biology-based model (DEBtox) to analyse bioassays in ecotoxicology: opportunities and recommendations. Environ Toxicol Chem 21: 459-465

$\begin{array}{llll}\text { PPDB } & \text { (Pesticide } & \text { Properties } & \text { DataBase) }\end{array}$ https://sitem.herts.ac.uk/aeru/ppdb/en/Reports/246.htm

Sijm DTHM, van der Linde A (1995) Size-dependent bioconcentration kinetics of hydrophobic organic chemicals in fish based on diffusive mass transfer and allometric relationships. Environ Sci Technol 29: 2769-2777

Sijm DTHM, Verberne ME, de Jonge WJ, Pärt P, Opperhuizen A (1995) Allometry in the uptake of hydrophobic chemicals determined in vivo and in isolated perfused gills. Toxicol Appl Pharmacol 131: 130-135

Sims RW, Gerard BM (1999) Earthworms. Earthworms: keys and notes for the identification and study of the species. Synopses of the British fauna. New series; 31. Shrewsbury: Field Studies Council. p169

Soetaert K, Petzoldt T, Setzer RW (2010) Solving Differential Equations in R: Package deSolve. Journal of Statistical Software, 33(9), 1--25. URL http://www.jstatsoft.org/v33/i09/ DOI 10.18637/jss.v033.i09 
642 Springett JA, Gray RAJ (1992) Effect of repeated low-doses of biocides on the earthworm Aporrectodea caliginosa in laboratory culture. Soil Biol Biochem 24(12): 1739-1744

644 Spurgeon DJ, Svendsen C, Kille P, Morgan AJ, Weeks JM (2004) Responses of earthworms 645 (Lumbricus rubellus) to copper and cadmium as determined by measurement of juvenile 646 traits in a specifically designed test system. Ecotox Environ Saf 57: 54-64

647 Steen Redeker E, Blust R (2004) Accumulation and toxicity of cadmium in the aquatic 648 oligochaete Tubifex tubifex: a kinetic modeling approach. Environ Sci Technol 38(2): $649 \quad 537-543$

650 Stürzenbaum SR, Kille P, Morgan AJ (1998) The identification, cloning and characterization 651 of earthworm metallothionein. FEBS Letters 431-437-442 